\title{
Effects of Diets on Lipogenic-Related Enzymes and on Lipoprotein and Hormone-Sensitive Lipases in the Adipose Tissue of Goats
}

\author{
Keiichi Tanaka, Shigeru OhtanI \\ and Kakichi SHIGeno \\ Faculty of Agriculture, Gifu University, \\ Gifu-shi 501-11
}

(Received December 15, 1982)

\begin{abstract}
The effects of shifting diets on fatty acid synthesis, on lipogenic-related enzyme activities, and on lipoprotein and hormone-sensitive lipase activities in the subcutaneous adipose tissue of goats were investigated. Six non-lactating goats were divided equally into two groups. The first group was shifted to the high-concentrate diet for 3 weeks after it received the roughage diet for 3 weeks. The second group was given the opposite treatment. Blood samples were taken from the jugular vein of each goat one hour before feeding. The subcutaneous adipose tissue and the liver were biopsied immediately before the diets were reversed. Glucose concentration in serum was higher in the high-concentrate diet feeding than in the roughage feeding, on the other hand, NEFA concentration in serum was higher in the roughage diet feeding. Both the lipogenesis and activities of lipogenic-related enzymes and the lipoprotein lipase activity in the subcutaneous adipose tissue, were higher in the high-concentrate diet feeding than in the roughage diet feeding; in contrast, the hormone-sensitive lipase activity was higher in the roughage diet feeding than in the high-concentrate diet feeding. The shifting of diets had no influence on activities of lipogenic-related enzymes in the liver of goats.

Jpn. J. Zootech. Sci., 54 (7): 470-480, 1983
\end{abstract}

The control of lipid metabolism has been extensively investigated in non-ruminant species $^{1-5}$. However, the regulatory mechanisms involved in lipogenesis and lipolysis in ruminants are poorly understood for the simple reason that only few studies have specifically dealt with the problem. Several studies have shown that adipose tissue enzyme patterns in ruminants differ significantly from non-ruminants ${ }^{6-11}$. The major difference between ruminants and non-ruminants is the form of nutrient energy, volatile fatty acids supplying most of the energy in ruminants, and glucose being the primary energy source in non-ruminants. That is, in monogastric animals given a highconcentrate diet, fatty acids are formed from glucose in both adipose tissue and liver. Although ruminants also eat large amounts of carbohydrate, this consists mainly of cellulose and hemicellulose, and these polymers are degraded in the rumen to yield acetate, propionate and butyrate. Very little glucose is absorbed from the gut in sheep on a normal diet ${ }^{12}$. Consequently, acetate is a major precursor of fatty acids in ruminants ${ }^{9,13,14}$. Using sheep killed 15 or $30 \mathrm{~min}$ after receiving a single dose of $\left(1^{14} \mathrm{C}\right)$ acetate, INGLE et $a l^{15)}$ found radioactivity distributed predominantly in the adipose tissue with only $8 \%$ in the liver and gastrointestinal tract and concluded 
that the adipose tissue was the predominant site of fatty acid synthesis in vivo.

The objective of this study was to investigate the effects of shifting diets on fatty acid synthesis and lipase activities in the ruminant adipose tissue. The effect on the fatty acid synthesis in the ruminant adipose tissue was measured by in vitro tissue incubations and these results coupled with changes in the activities of enzymes associated with acetate incorporation into fatty acids and NADPH generation.

\section{Materials and Methods}

\section{Experimental animals and design}

Six non-lactating goats (Japanese Saanen) weighing 22 to $28 \mathrm{~kg}$ (2 years old) were divided equally into two groups. One group was subjected to a roughage diet for 3 weeks, thereafter, it was shifted to a high-concentrate diet also for 3 weeks (R-C group). The second group was given an opposite treatment, that is, animals were first given the high-concentrate diet for 3 weeks followed by the roughage diet also for 3 weeks (C-R group). Each goat was fed alfalfa hay cube of $19 \mathrm{~g}$ per a day per $1 \mathrm{~kg}$ body weight (TDN intake $10 \mathrm{~g} / \mathrm{day} / 1 \mathrm{~kg}$ body weight) during the roughage diet feeding, and alfalfa hay cube of $4 \mathrm{~g}$ per a day per $1 \mathrm{~kg}$ body weight (TDN intake $2 \mathrm{~g}$ / day $/ 1 \mathrm{~kg}$ body weight) and concentrates of $12 \mathrm{~g}$ per a day per $1 \mathrm{~kg}$ body weight (TDN intake $8 \mathrm{~g} / \mathrm{day} / 1 \mathrm{~kg}$ body weight) during the high-concentrate diet feeding. The concentrate diet consisted of corn $37.0 \%$, fish meal $1.9 \%$, soybean meal $46.7 \%$, wheat bran $11.1 \%$ and $\mathrm{CaCO}_{3} 3.3 \%$. Adipose and liver samples of goats were taken out immediately before the goats were shifted on the third week from the roughage diet to the high-concentrate diet ( $\mathrm{R}-\mathrm{C}$ group) or from the high-concentrate diet to the roughage diet ( $\mathrm{C}-\mathrm{R}$ group).

\section{Tissues and blood sampling}

One to two g samples of adipose tissue and liver were biopsied from each goat immediately before feeding. Adipose biopsies were obtained by cutting with a scalpel trom the subcutaneous adipose tissue over the longissimus muscle in the rib area. Liver biopsies were obtained by inserting the hand in the abdominal cavity and then pinching out the margin of the liver with the thumb and the fore and middle fingers. The skin around the incision site was shaved, disinfected and anesthetized with $4 \sim 5 \mathrm{ml}$ a subcutaneous injection of procaine hydrochloride. Skin and subcutaneous tissues were incised with a scalpel $5 \mathrm{~cm}$ ventrally to the anesthetized line. Samples of adipose tissues and livers were placed in an ice-cold $0.25 \mathrm{M}$ sucrose solution containing $1 \mathrm{mM}$ EDTA.

Ten $\mathrm{m} l$ blood sample were taken from the jugular vein of each goat one hour before feeding. Serum was separated by centrifugation from the blood collected. It was used for the determinations of the non-esterified fatty acids (NEFA) and glucose levels in the serum, which were carried out in accordance with the simplified procedures suggested by the mini-manual enclosed in the NEFA-Test kit and Glucose C-Test kit from a commercial chemical manufacture-distributor (Wako Junyaku Kogyo K. K.). 


\section{Metabolic studies}

Liver slices weighing $150 \sim 200 \mathrm{mg}$ were prepared in the cold with a Stadie-Riggs hand microtome, and placed in $50 \mathrm{ml}$ incubation flasks containing $3 \mathrm{~m} l$ of Krebs-Ringer bicarbonate buffer $\left(\mathrm{Ca}^{++}-\right.$free, $\left.\mathrm{pH} 7.4\right)$. The buffer contained $10 \mu$ moles acetate and $0.33 \mu \mathrm{Ci}$ acetate $-1{ }^{14} \mathrm{C}$ (sodium salt, New England Nuclear) per $\mathrm{ml}$. The flasks were sealed with rubber serum stoppers with two polyethylene tubes and a hanging plastic well containing a rolled $2 \times 2 \mathrm{~cm}$ piece of Whatman No. 1 filter paper, and then gassed with $0_{2}+\mathrm{CO}_{2}(95: 5, \mathrm{v} / \mathrm{v})$ by running the mixed gas through the tubes, and after the tubes were stoppered, the flasks were incubated at $37^{\circ} \mathrm{C}$ for 3 hours in a shaking water bath with 60 strokes per minutes. At the end of the incubation period, the filter paper in the center well was saturated with $0.16 \mathrm{ml}$ of $40 \% \mathrm{KOH}$ and $1.0 \mathrm{~m} l$ of $0.1 \mathrm{~N} \mathrm{H}_{2} \mathrm{SO}_{4}$ was added to incubation medium to liberate $\mathrm{CO}_{2}$. Shaking was continued for 30 minutes to ensure complete liberation and trapping of the $\mathrm{CO}_{2}$. The filter paper containing the radioactive $\mathrm{CO}_{2}$ was transferred to a liquid scintillation vial, allowed to dry and spread flat in the bottom of the vial. Before counting, $10 \mathrm{ml}$ of toluene scintillatin solution ( $4 \mathrm{~g}$ 2,5-diphenyloxazole, $0.1 \mathrm{~g} \mathrm{1,4-bis}\{2-(5-$ phenyloxazolyl) $\}$ -benzene and 1 liter of toluene) was added. Radioactivity was determined with a liquid scintillation spectrometer.

Following incubation the tissues were rinsed three times with $0.9 \%$ saline, after which total lipids were extracted with chloroform-methanol $(2: 1, \mathrm{v} / \mathrm{v})$. The lower (chloroform) layer was allowed to evaporate to dryness. After drying, $10 \mathrm{~m} l$ petroleum ether was added, out of which $1.0 \mathrm{ml}$ was transfered to a liquid scintillation vial. The petroleum ether was evaporated in a $45^{\circ} \mathrm{C}$ water bath under a stream of oxygenfree nitrogen and the residue was dissolved in $10 \mathrm{ml}$ toluene scintillation solution and was then counted for total lipids. The remaining $9 \mathrm{~m} l$ petroleum ether was also evaporated. After drying, it was saponified with $3 \mathrm{~m} l$ of alcohol-KOH (20:1, v/v). This was later acidified with $\mathrm{HCl}$ and the fatty acids were removed by successive $5 \mathrm{ml}$ extraction with petroleum ether. The combined ether extracts were backwashed with water, and the other fraction was transferred to liquid scintillation vials. The ether was evaporated and the fatty acids dissolved in $10 \mathrm{~m} l$ of scintillation solution, then counted.

\section{Enzyme Assays}

A portion of the tissue was weighed and homogenized in 10 volumes of an ice-cold $0.25 \mathrm{M}$ sucrose solution containing $1 \mathrm{mM}$ EDTA. Homogenates were centrifuged at $600 \times \mathrm{g}$ at $4^{\circ} \mathrm{C}$ for 10 minutes. The supernatants were recentrifuged at $15,000 \times \mathrm{g}$ for 30 minutes at $4^{\circ} \mathrm{C}$ and the clear supernatant was used for assaying enzymes and protein. NADP-isocitrate dehydrogenase (EC 1.1.1.43, NADP-ICDH), glucose-6phosphate dehydrogenase (EC 1.1.1.49, G6PDH), 6-phosphogluconate dehydrogenase (EC 1.1.1.44,6PGDH), NADP-malate dehydrogenase (EC 1.1.1.40, NADP-MDH) and citrate cleavage enzyme (EC 4.1.3.8, OCE) were assayed by the methods of Bernt and BergmeYer ${ }^{16)}$, LOHR and WALLER ${ }^{17)}, \mathrm{KING}^{18)}$, OchOA ${ }^{19)}$ and TAKeDA et al. ${ }^{20)}$, respectively. All assays were conducted at $25^{\circ} \mathrm{C}$. Enzyme activity is expressed as units 
Diets and Lipogenesis in Goats

Table 1. Effects of the shift of diets on body weights and crude fiber intakes of goats

\begin{tabular}{|c|c|c|c|c|}
\hline \multirow{3}{*}{ Goat No. } & \multicolumn{4}{|c|}{ Experimental treatments } \\
\hline & \multicolumn{2}{|c|}{ Roughage diet } & \multicolumn{2}{|c|}{ High concentrate diet } \\
\hline & Body weight & $\begin{array}{l}\text { Crude fiber } \\
\text { intake }\end{array}$ & Body weight & $\begin{array}{l}\text { Crude fiber } \\
\text { intake }\end{array}$ \\
\hline $\mathrm{R}-\mathrm{C}$ group ${ }^{11}$ & $\mathrm{~kg}$ & $\mathrm{~g} /$ day & $\mathrm{kg}$ & $\mathrm{g} / \mathrm{day}$ \\
\hline 1 & 25.8 & 182.0 & 24.6 & 91.8 \\
\hline 2 & 26.6 & 187.8 & 24.2 & 90.3 \\
\hline 3 & 27.2 & 192.0 & 27.8 & 103.7 \\
\hline \multicolumn{5}{|l|}{ C - R group gr $^{2}$} \\
\hline 4 & 24.8 & 175.1 & 24.2 & 90.3 \\
\hline 5 & 22.8 & 161.0 & 22.2 & 82.8 \\
\hline 6 & 26.8 & 189.2 & 25.4 & 94.8 \\
\hline
\end{tabular}

1) Shifted from the roughage diet to the high-concentrate diet. 2) Shifted from the high-concentrate diet to the roughage diet.

per $100 \mathrm{mg}$ protein, where a unit is the amount of enzyme which will catalyze the utilization of one nanomole of substrate per minute at $25^{\circ} \mathrm{C}$.

Activities of lipoprotein and hormone-sensitive lipases (LPL and HSL) in the adipose tissue were measured by the method of HASEGAwA et al. ${ }^{21}$. Activities of both lipases were expressed as $\mu$ moles fatty acid released per mg protein. The protein content of the supernatant used for enzyme assay were determined by the method of LowRY et al. ${ }^{22)}$.

\section{Results}

There were no differences in body weights between the roughage-concentrate ( $R$ C) and the concentrate-roughage (C-R) group, although the roughage diet feeding resulted in twice crude fiber intakes of the high-concentrate diet feeding (Table 1).

The effects of shifting the diet on the concentrations of glucose and NEFA in the serum of goats are shown in Table 2. In the $\mathrm{R}-\mathrm{C}$ group, the serum concentration of

Table 2. Effects of the shift of diets on concentrations of glucose and NEFA in serum of goats

\begin{tabular}{|c|c|c|c|c|}
\hline \multirow[b]{2}{*}{ Goat No. } & \multicolumn{2}{|r|}{ Glucose } & \multicolumn{2}{|r|}{ NEFA } \\
\hline & $\begin{array}{c}\text { Roughage } \\
\text { diet }\end{array}$ & $\begin{array}{c}\text { High-concentrate } \\
\text { diet }\end{array}$ & $\begin{array}{c}\text { Roughage } \\
\text { diet }\end{array}$ & $\begin{array}{c}\text { High-concentrate } \\
\text { diet }\end{array}$ \\
\hline $\mathrm{R}-\mathrm{C}$ group ${ }^{1)}$ & \multicolumn{2}{|c|}{$-\mathrm{mg} / 100 \mathrm{~m} l-$} & \multicolumn{2}{|c|}{$\longrightarrow \mathrm{Eq} / l \longrightarrow$} \\
\hline 1 & 50.0 & 84.8 & 52.6 & 17.5 \\
\hline 2 & 57.3 & 72.2 & 60.7 & 30.7 \\
\hline 3 & 56.3 & 78.1 & 99.6 & 47.0 \\
\hline \multicolumn{5}{|l|}{ C-R group ${ }^{2}$} \\
\hline 4 & 64.6 & 86.1 & 87.7 & 30.7 \\
\hline 5 & 50.6 & 76.2 & 70.2 & 35.1 \\
\hline 6 & 55.2 & 70.8 & 94.4 & 26.3 \\
\hline
\end{tabular}

1), 2) See footnote of Table 1. 
glucose was increased and that of NEFA was decreased by the shift from the roughage diet to the high-concentrate diet. In contrast, these concentrations were the reverse in the $\mathrm{C}-\mathrm{R}$ group, that is, the glucose concentration was higher in the high-concentrate diet feeding than in the roughage diet feeding, while NEFA concentration in serum were higher in the roughage diet feeding than in the high-concentrate diet feeding.

Fig. 1 and Table 3 show the effects of the shift in the diet on lipogenesis and enzymatic activities in the adipose tissue and in the liver of goats. The shift in the diet in the R-C group resulted in increased lipogenesis from acetate and activities of lipogenic-related enzyme in the subcutaneous adipose tissue of goats. On the other hand, the shift in the diet in the C-R group resulted in opposite results in the $\mathrm{R}-\mathrm{C}$
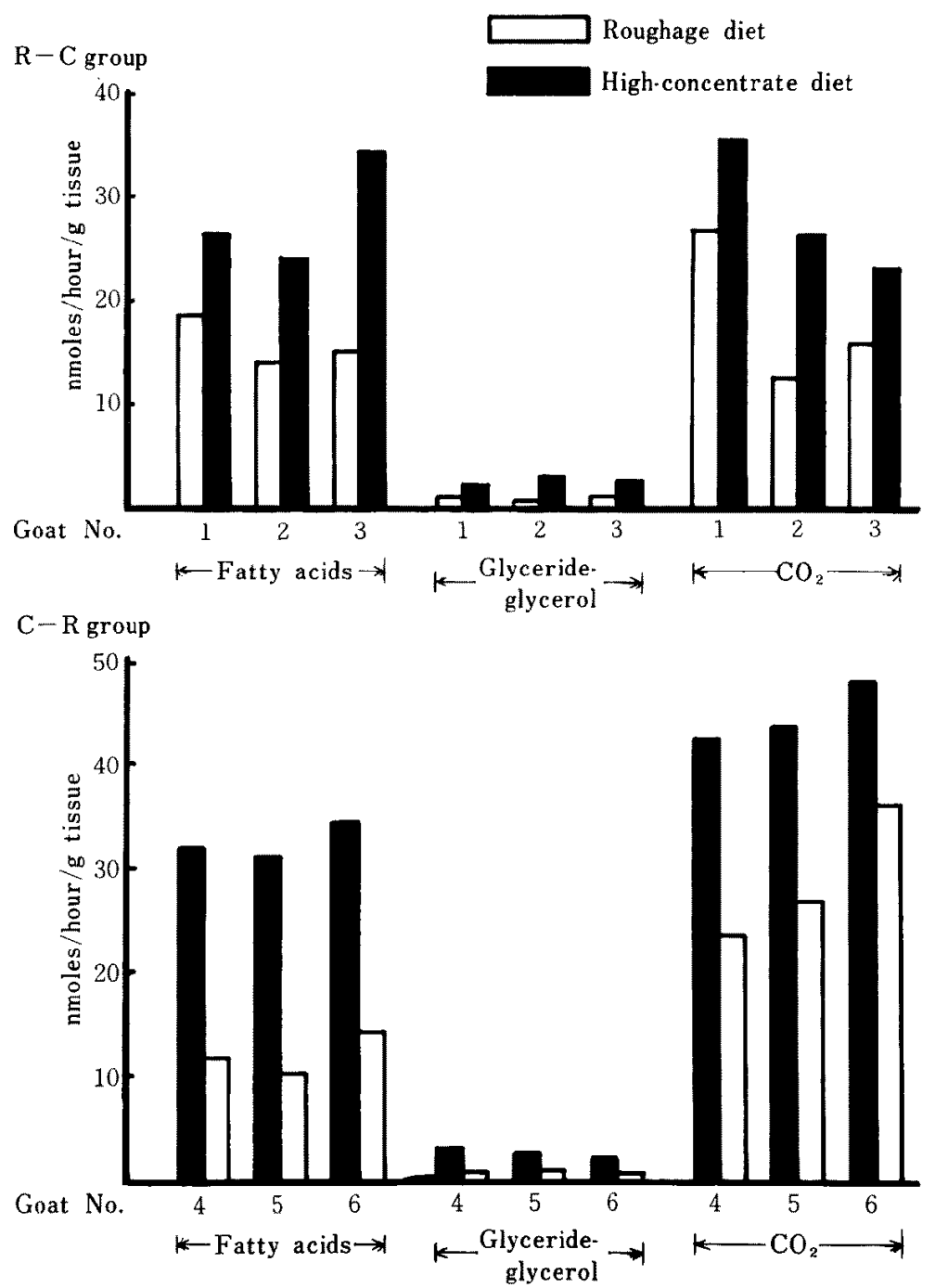

Fig. 1. Effects of the shift of diets on lipogenesis and $\mathrm{CO}_{2}$ production in the subcutaneous adipose tissue of goats. 
group. $\mathrm{CO}_{2}$ production from acetate in the subcutaneous adipose tissue was similar to results obtained from the lipogenesis and the activities of lipogenic-related enzymes. The shift in the diet had no influences on activities of lipogenic-related enzymes in the liver of goats.

The effects of the shift in the diet on activities of LPL and HSL in the subcutaneous adipose tissue of goats are shown in Table 4. In the $\mathrm{R}-\mathrm{C}$ group, the activities of LPL and HSL in the subcutaneous adipose tissue were increased and decreased, respectively, by the shift from the roughage diet to the high-concentrate diet. In the $\mathrm{C}-\mathrm{R}$ group, the shift from the high-concentrate diet to the roughage diet resulted in an increase in HSL activity in the subcutaneous adipose tissue, while the LPL activity in the subcutaneous adipose tissue was decreased in two of goats, but remained unchanged in the last one.

\section{Discussion}

Biopsies of subcutaneous adipose tissue and liver samples from non-lactating goats caused a slight decrease in feed intake. However, feed intake returned to normal within two to three days after surgery.

In the present experiment, activities of lipogenic-related enzymes in the liver were marked lower compared to the subcutaneous adipose tissue. Although Martin et al. $^{23)}$ have reported that activities of pentose phosphate dehydrogenases in liver tended to be higher in wethers fed concentrate diets, results of the present experiment showed no significant differences in G6PDH and 6PGDH activities in liver of goats fed either roughage or high-concentrate diets. Adaptive changes in pentose phosphate dehydrogenases activities in liver would have been anticipated if the liver was an importent organ in lipid synthesis, since these enzymes are involved in supplying reducing equivalents for fatty acid synthesis. However, it is well estabished that lipogenesis in ruminants occurs primarily in the adipose tissue and not in the liver ${ }^{10.15 .24-28)}$. In the present experiment, feeding diet with high proportions of concentrates to goats resulted in higher fatty acid synthesis in the subcutaneous adipose tissue than feeding roughage. Our results which induced the adaptive changes in the subcutaneous adipose tissue of goats are consistent with the observations obtained in sheep and beef steers ${ }^{23,29}$. Furthermore, in the present experiment, the more dramatic changes in activities of pentose phosphate dehydrogenases in the subcutaneous adipose tissue occurred in goats fed the high-concentrate diet. The stimulatory effects of the high-concentrate diet on G6PDH activity in sheep adipose tissues have been reported ${ }^{30-32}$. This shows that pentose phosphate pathway could make a major contribution to NADPH production in adipose tissues of ruminants fed the high-concentrate diet. In rat adipose tissues, it is thought that the NADPH required for fatty acid synthesis, which is not supplied by the pentose phosphate pathway, is produced by NADP-MDH ${ }^{33-37)}$. The adipose tissue from ruminants has relatively low activities of $\mathrm{NADH}-\mathrm{MDH}^{31,38-43)}$. Thus, it is generally thought that malate-transhydrogenation cycle has a minor role in NADPH production in ruminant 
Tanaka, Ohtani and Shigeno

Table 3. Effects of the shift of diets on activities of lipogenic-related enzymes in the subcutaneous adipose tissue and liver of goats

\begin{tabular}{|c|c|c|c|c|}
\hline & \multirow[b]{2}{*}{ Enzyme } & \multirow[b]{2}{*}{ Goat No. } & \multicolumn{2}{|c|}{ Experimental treatments } \\
\hline & & & $\begin{array}{c}\text { Roughage } \\
\text { diet }\end{array}$ & $\begin{array}{l}\text { High-concentrate } \\
\text { diet }\end{array}$ \\
\hline \multirow{16}{*}{$\begin{array}{l}\text { Subcutaneous } \\
\text { R-C group }{ }^{13}\end{array}$} & adipose tissue & & \multicolumn{2}{|c|}{$\mathrm{nmoles} / \mathrm{min} / \mathrm{mg}$ protein } \\
\hline & \multirow{3}{*}{$\mathrm{G} \mathrm{PDH}^{21}$} & 1 & 65.8 & 149.8 \\
\hline & & 2 & 85.8 & 105.4 \\
\hline & & 3 & 51.4 & 137.3 \\
\hline & \multirow[t]{3}{*}{$6 \mathrm{PGDH}^{2 !}$} & 1 & 37.4 & 89.3 \\
\hline & & 2 & 43.8 & 74.7 \\
\hline & & 3 & 27.0 & 81.6 \\
\hline & \multirow[t]{3}{*}{ NADP-ICDH ${ }^{2 /}$} & 1 & 119.8 & 185.9 \\
\hline & & 2 & 125.6 & 155.8 \\
\hline & & 3 & 82.5 & 153.7 \\
\hline & \multirow[t]{3}{*}{ NADP-MDH } & 1 & 13.9 & 34.9 \\
\hline & & 2 & 17.3 & 26.3 \\
\hline & & 3 & 13.8 & 21.3 \\
\hline & \multirow[t]{3}{*}{$\mathrm{CCE}^{21}$} & 1 & 13.1 & 34.9 \\
\hline & & 2 & 13.8 & 21.3 \\
\hline & & 3 & 5.2 & 23.8 \\
\hline \multicolumn{5}{|l|}{$\mathrm{C}-\mathrm{R}$ group ${ }^{3)}$} \\
\hline & \multirow[t]{3}{*}{$\mathrm{G}_{6} \mathrm{PDH}^{2)}$} & 4 & 46.3 & 64.7 \\
\hline & & 5 & 35.9 & 70.6 \\
\hline & & 6 & 53.2 & 91.8 \\
\hline & \multirow[t]{3}{*}{$6 \mathrm{PGDH}^{21}$} & 4 & 39.8 & 56.9 \\
\hline & & 5 & 34.6 & 66.5 \\
\hline & & 6 & 32.5 & 59.7 \\
\hline & \multirow[t]{3}{*}{ NADP $-\mathrm{ICDH}^{27}$} & 4 & 98.4 & 128.9 \\
\hline & & 5 & 122.9 & 147.3 \\
\hline & & 6 & 79.6 & 128.5 \\
\hline & \multirow[t]{3}{*}{ NADP $-\mathrm{MDH}^{2)}$} & 4 & 9.7 & 22.1 \\
\hline & & 5 & 8.8 & 19.1 \\
\hline & & 6 & 11.5 & 25.2 \\
\hline \multirow{2}{*}{\multicolumn{5}{|c|}{$\begin{array}{l}\text { Liver } \\
\qquad \text { R-C group } 11\end{array}$}} \\
\hline & & & & \\
\hline & \multirow[t]{3}{*}{$\mathrm{G}_{6} \mathrm{PDH}^{23}$} & 1 & 5.0 & 5.8 \\
\hline & & 2 & 4.8 & 7.4 \\
\hline & & 3 & 4.0 & 2.7 \\
\hline & \multirow[t]{3}{*}{$6 \mathrm{PGDH}^{2)}$} & 1 & 21.0 & 20.3 \\
\hline & & 2 & 20.0 & 23.3 \\
\hline & & 3 & 15.7 & 17.6 \\
\hline & \multirow[t]{3}{*}{ NADP-1CDH ${ }^{21}$} & 1 & 143.0 & 140.7 \\
\hline & & 2 & 132.5 & 126.8 \\
\hline & & 3 & 138.9 & 145.8 \\
\hline & \multirow[t]{3}{*}{ NADP-MDH ${ }^{2)}$} & 1 & 4.2 & 3.9 \\
\hline & & 2 & 3.9 & 4.8 \\
\hline & & 3 & 3.6 & 2.6 \\
\hline & \multirow[t]{4}{*}{$\mathrm{CCE}^{2)}$} & 1 & 1.1 & 0.6 \\
\hline & & 2 & 0.3 & 0.8 \\
\hline & & 3 & 0.2 & 0.4 \\
\hline & & 476 & & \\
\hline
\end{tabular}


Diets and Lipogenesis in Goats

Table 3. (Continued)

\begin{tabular}{|c|c|c|c|c|}
\hline & \multirow[b]{2}{*}{ Enzyme } & \multirow[b]{2}{*}{ Goat No. } & \multicolumn{2}{|c|}{ Experimental treatments } \\
\hline & & & $\begin{array}{c}\text { Roughage } \\
\text { diet }\end{array}$ & $\begin{array}{l}\text { High-concentrate } \\
\text { diet }\end{array}$ \\
\hline \multicolumn{2}{|c|}{$\begin{array}{l}\text { Subcutaneous adipose tissue } \\
\text { C-R group }\end{array}$} & & \multicolumn{2}{|c|}{ nmoles $/ \mathrm{min} / \mathrm{mg}$ protein } \\
\hline & $\mathrm{G}_{6} \mathrm{PDH}^{2 /}$ & 4 & 8.7 & 5.3 \\
\hline & & 5 & 7.0 & 8.3 \\
\hline & & 6 & 2.0 & 4.5 \\
\hline & $6 \mathrm{PGDH}^{2 \prime}$ & 4 & 19. 1 & 19.4 \\
\hline \multirow{2}{*}{\multicolumn{2}{|c|}{. }} & 5 & 26.4 & 22.9 \\
\hline & & 6 & 19. 1 & 22.5 \\
\hline \multirow{3}{*}{\multicolumn{2}{|c|}{ NADP-ICDH ${ }^{2)}$}} & 4 & 119.8 & 132.3 \\
\hline & & 5 & 107.0 & 91.3 \\
\hline & & 6 & 134.5 & 141.7 \\
\hline \multirow{3}{*}{\multicolumn{2}{|c|}{$\mathrm{NADP}-\mathrm{MDH}^{2}$}} & 4 & 2. 4 & 4.0 \\
\hline & & 5 & 3.9 & 5.1 \\
\hline & & 6 & 3.8 & 5.0 \\
\hline \multirow{3}{*}{\multicolumn{2}{|c|}{$\mathrm{CCE}^{21}$}} & 4 & 0.1 & 0.4 \\
\hline & & 5 & 0.1 & 0.3 \\
\hline & & 6 & 0.4 & 0.3 \\
\hline
\end{tabular}

1), 3) See footnote of Table 1. 2) Activity expressed as nano moles substrate converted to product per minute per $\mathrm{mg}$ protein at $25^{\circ} \mathrm{C}$.

Table 4. Effects of the shift of diets on activities of lipoprotein lipase and hormone-sensitive lipase in the subcutaneous adipose tissue of goats

\begin{tabular}{|c|c|c|c|c|}
\hline & \multirow[b]{2}{*}{ Enzyme } & \multirow[b]{2}{*}{ Goat No. } & \multicolumn{2}{|c|}{ Experimental treatments } \\
\hline & & & $\begin{array}{c}\text { Roughage } \\
\text { diet }\end{array}$ & $\begin{array}{l}\text { High-concentrate } \\
\text { diet }\end{array}$ \\
\hline \multirow[t]{7}{*}{$\mathrm{R}-\mathrm{C}$ group ${ }^{11}$} & & & \multicolumn{2}{|c|}{$\mu$ moles/hour/mg protein } \\
\hline & $\mathrm{LPL}^{a)}$ & 1 & 146.2 & 324.7 \\
\hline & & 2 & 180.8 & 583.2 \\
\hline & & 3 & 158.0 & 295.3 \\
\hline & $\mathrm{HSL}^{\mathrm{q})}$ & 1 & 47.6 & 22.5 \\
\hline & & 2 & 58.3 & 17.8 \\
\hline & & 3 & 71.5 & 26.6 \\
\hline \multicolumn{5}{|l|}{ C-R group $^{81}$} \\
\hline & LPL $^{23}$ & 4 & 116.8 & 267.0 \\
\hline & & 5 & 128.6 & 328.6 \\
\hline & & 6 & 158.8 & 169.6 \\
\hline & $\mathrm{HSL}^{21}$ & 4 & 112.6 & 40.2 \\
\hline & & 5 & 94.5 & 43. 4 \\
\hline & & 6 & 120.6 & 35.6 \\
\hline
\end{tabular}

1), 3) See footnote of Table 1. 2) Activity expressed as $\mu$ moles fatty acid released per hour per $\mathrm{mg}$ protein at $37^{\circ} \mathrm{C}$. 
adipose tissues. Also, CCE activity in sheep adipose tissues is lower than that in rat adipose tissues ${ }^{40)}$. The relatively low activity of CCE in ruminant adipose tissues is thought to be the reason for the low rate of utilization of glucose for fatty acid synthesis in ruminant adipose tissues ${ }^{40}$. Once ruminants have acquired a functional rumen, acetate becomes the principal carbon source for fatty acid synthesis in the adipose tissue. This was first demonstrated by Hanson and BALLARD ${ }^{10,40)}$ and they also demonstrated that the adipose tissue had only a very limited ability to utilize glucose carbon for fatty acid synthesis. However, in the present experiment, activities of NADP-MDH and CCE in the subcutaneous adipose tissue showed a marked response to diet. That is, goats fed the high-concentrate diet had higher activities of NADP-MDH and CCE in the subcutaneous adipose tissue than did goats fed the roughage diet. An increase in the concentration of serum glucose should be induced by an increase in net glucose uptake by portal vein or in gluconeogenesis from propionate through feeding the high-concentrate diet to goats and should also increase the availability of glucose. Thus, it is possible that in goats, increased availability of glucose leads to an increase in both the rate of glucose conversion to fatty acids and activities of these enzymes (NADP-MDH and CCE).

In the present experiment, the activity of NADP-ICDH in the subcutaneous adipose tissue was found to be higher in goats fed the high-concentrate diet. A number of reports show that NADP-ICDH is the most active of the NADP-linked dehydrogenases in the cytosol of the ruminant adipose tissue ${ }^{23,41,33.44)}$. It has thus been proposed that in ruminants it is NADP-ICDH rather than NADP-MDH which provides the NADPH for fatty acid synthesis not produced by the pentose phosphate cycle ${ }^{26,38,45}$. In the present experiment, the adaptive responses of this enzyme would support this proposition.

The type of diet fed had a pronounced effect on the rate of fatty acid synthesis and on the activities of lipogenic-related enzymes in the ruminant adipose tissue. Although glucose carbon is little used for fatty acid synthesis in the ruminant adipose tissue, addition of glucose increased by 3-10 fold the rate of fatty acid synthesis from acetate in ovine adipose tissues ${ }^{9.39 .40,45-47}$. In most of these studies, insulin was added along with the glucose, but it was subsequently confirmed that it was glucose rather than insulin which was major stimulant ${ }^{45,46}$. The effect of glucose is thought to be due to increased NADPH and glycerol-3-phosphate production ${ }^{25,41,43}$. In the present experiment, feeding the high-concentrate diet to goats resulted in an increase in glucose concentration in serum. Such an increase in glucose concentration in serum may increase glucose uptake by the subcutaneous adipose tissue of goats and thereafter increase the rate of fatty acid synthesis and activities of lipogenic-related enzymes in the subcutaneous adipose tissue of goats.

Feeding the high-concentrate diet to goats decreased HSL activity, but increased activity of LPL, in the subcutaneous adipose tissue. Feeding such a diet to goats increases the rates of fatty acid synthesis, of lipolysis of circulating triglycerides by LPL (an increase in the adipose tissue LPL activity is indicative of triglyceride uptake by the adipose tissue) and of fatty acid esterification, and decreases the rate of 
lipolysis by HSL to the adipose tissue, all of which lead to increased lipid deposition in the adipose tissue.

\section{References}

1) Tepperman, J, and H. M. Tepperman, Fed. Proc., 29: 1284-1293. 1970.

2) Hanson, R. W., M. S. Patel, M. Jomain-Baum and F. J. Ballard, Metabolism, 20: 27-42. 1971.

3) Flatt, J.P., in Adipose Tissue, Regulation and Metabolic Functions (Jeanrenaud, B. and Hepp, D. eds.) 93. Academic Press. New York, 1970.

4) Vagelos, P. R., in Current Topics in Cellular Regulation (Horecker, B. L. and E. R. Stadtman, eds.) 119. Academic Press. New York. 1971.

5) Romsos, D. R. and G. A. Leveille, in Modification of Lipid Metabolism (Perkins, E. G. and L. A. Witring, eds.) 127-142. Academic Press, New York, 1975.

6) Baldwin, R. L., J. Dairy Sci., 49: 1533-1542. 1966.

7) Baldwin, R. L., M. Ronning, C. Radanovics and G. Plange, J. Nutr., 90: 47-55. 1966.

8) Wallace, J. C. and E. A. Newsholme; Biochem. J., 104;378-384. 1967.

9) Ballard, F. J., R. W. Hanson and D. S. Kronfeld, Fed. Proc., 28: 218-231. 1969.

10) Hanson, R. W. and F. J. Ballard, Biochem. J., 108: 705-713, 1968.

11) Bauman, D. E., R. E. Brown and C. L. Dayis, Arch. Biochem. Biophys., 140: 237-244. 1970.

12) Katz, M. L. and E. N. Bergman, Amer. J. Physiol, 216: 953-960. 1969.

13) Bauman, D. E., Fed. Proc., 35: 2308-2313. 1976.

14) Prior, R. L., J. Nutr., 108: 926-935. 1978.

15) Ingle, D. L., D. E. Bauman and U. S. Garrigus, J. Nutr., 102: 617-624, 1972.

16) Bernt, E. and H. U. Bergmeyer, in Methods of Enzymatic Analysis vol. 2. (Bergmeyer, H. U. ed.) 625-631. Academic Press. New York and London. 1974.

17) Löhr, G. W. and H. D. Waller, in Methods of Enzymatic Analysis vol. 2. (Bergmeyer, H. U. ed.) 636-643. Academic Press. New York and London. 1974.

18) King, J., in Methods of Enzymatic Analysis vol. 2. (Bergmeyer, H. U. ed.) 632-635. Academic Press. New York and London. 1974.

19) Ochoa, S., in Methods in Enzymology vol. 1. (Colowisk, S. P. and N. O. Kaplan, eds.) 739747. Acadcmic Press. New York. 1955.

20) Takeda, Y., F. Suzuki and H. Inoue, in Methods in Enzymology vol. 13. (Lowenstein, J. M. ed.) 153-155. Academic Press. New York and London. 1968.

21) Hasegawa, S., K. Satro, Y. Hikamt and T. Mizuno, Jpn. J. Zootech. Sei., 51: 360-367. 1980.

22) Lowry, O. H., N. J. Rosebrough, A. L. Farr and R. T. Randall, J. Biol. Chcm., 193: 265-275. 1951.

23) Martin, R. J., L. L. Wilson, R. L. Cowan and J. D. Sink, J. Anim. Sci., 36: 101-106. 1973.

24) Hood, R. L., E. H. Thompson and C. E. Allen, Inter. J. Biochem., 3: 598-606. 1972.

25) Ingle, D. L., D. E. Bauman and U. S. Garrigus, J. Nutr., 102：609-616. 1972.

26) Liepa, G. U., D. C. Beitz and J. R. Linder, J. Nutr,, 108: 1733-1739. 1978.

27) Payne, E. and C. J. Masters, Int. J. Biochem., 2: 623-643. 1971.

28) Howarth, R. E., R. L. Baldwin and M. Ronning, J. Dairy Sci., 51: 1270-1274. 1968.

29) Scott, R. A. and R. L. Prior, J. Anim. Sci., 50: 137-144. 1980.

30) Opstyedt, J., R. L. Baldwin and M. Ronning, J. Dairy Sci., 50: 108-109. 1967.

31) Baldwin, R. L., H. J. Lin, W. Cheng, R. Cabrera and M. Ronning, J. Dairy Sci., 52: $183-187$. 1969.

32) Young, J. W., S. L. Thorp and H. Z. Delumen, Biochem. J., 114: 83-88. 1969.

33) Flatt, J.P. and E. G. Ball, J. Biol. Chcm., 239: 675-685, 1964.

34) Kather, H. and K. Brand, Arch. Biochcm. Biophys., 170: 417-426. 1975.

35) Rognstad, R. and J. Katz, Proc. Nat. Acad. Sci., 55: 1148-1156. 1966.

36) Wise, E. M. and E. G. Batl, Proc. Nat. Acad. Sci., 52： 1255-1263. 1964.

37) Young, J. W., E. Shrago and H. A. Lardy, Biochemistry, 3: 1687-1692. 1964.

38) Baldwin, R. L., J. R. Reichl, S. Lours, N. E. Smith, Y. T. Young and E. Osborne, J. Dairy Sci., 56: 340-349. 1973.

39) Ballard, F. J., O. H. Filsell and I. G. Jarrett, Biochem. J., 126: 193-200. 1972.

40) Hanson, R. W. and F. J. Ballard, Biochem. J., 105: 529-536. 1967. 
41) Ingle, D. L., D. E. Bauman, R. W. Mellenberger and D. E. Johnson, J. Nutr., 103: 1479-1488. 1973.

42) Martin, R. J. and L. L. Wilson, J. Anim. Sci., 39: 865-870. 1974.

43) Vernon, R. G., Lipids, 11: 662-669. 1976.

44) Yanc, Y. T., R. L. Baldwin and W. N. Garrett, J. Anim. Sci., 47: 686-690. 1978.

45) Yang, Y. T. and R. L. Baldwin, J. Dairy Sci., 56: 350-356. 1973.

46) Vernon, R. G., Int. J. Biochem., 8: 517-523. 1977.

47) Whitehurst, G. B., D. C. Beitz, M. A. Pothoven, W. R. Ellison and M. H. Crump, J. Nutr., 108: $1806-1811.1978$.

\title{
ヤギ脂肪組織中の脂肪酸合成関連酵素および \\ リパーゼ活性におよぼす飼料変換の影響
}

\author{
由中桂一・大谷 滋・重野嘉吉
}

汥皁大学農学部，岐阜市楖户 501-11

ヤギに給与する飼料を变換することによって，皮下脂 肪組織における脂質合成能と脂肪酸合成関連醉素および リポプロティンリパーゼとホルモン感受性リパーゼの活 性にどの上らな影響があらわれるかについて检討した。

乾乳中のヤギ 6 頭 (日本ザーネン種, 体重 $22 \sim 28 \mathrm{~kg}$ ) を，3頭づつの 2 群に分けて供試した。第 1 群は粗飼料 のみ它 3 週間給与した後，浱厚飼料多給に变換し，3週 間飼育した。籍 2 群は，第 1 群と适の処理を行った。い ずれの群においても、飼料を变換する1時間前に探血を, また直前に生众によって皮下栺肪組織上朋臓をそれぞれ $1 \sim 2 \mathrm{~g}$ 摘出した。

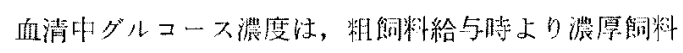

多給時の方が高く，一方血清中遊離型脂肪酸濃度は粗飼 料給与時において高い值を示した，皮下脂肪組瀻におけ る脂肪酸合成能および脂肪酸合成関連酵素とリポプロテ インリパーゼの活性は, 粗飼料給与時に比べて, 潈厚飼 料多給㭙の方が高い值を示した。一方ホルモン感受性り パーゼ活性江粗鲇料給与時の方が高かった。これらの結 果は, 粗飼料給与時より濃厚飼料多給時の方が皮下脂肪 組繊一の脂肪蓄皘が增大寸ることを裹付けているように 思われる。

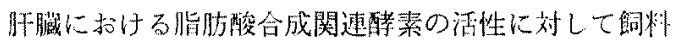
の変換による影淿は锥察されなかった。

日篦会解， $54(7) ： 470-480 ， 1983$ 